\title{
Article
}

\section{Agglomeration Behavior of Particles in a Molten Polymer in a Steady Shear Flow}

\author{
Yoshiyuki Komoda, Kanako Kameyama, Emi Hasegawa, Hiroshi SuzuKI, and Hiromoto Usui \\ Department of Chemical Science and Engineering, Graduate School of Engineering, Kobe University \\ 1-1, Rokkodai-cho, Nada-ku, Kobe, Hyogo 657-8501, Japan
}

\begin{abstract}
The behavior of the particle agglomerate in a polymer melt in dispersion and agglomeration processes was investigated. In the dispersion process of particle agglomerates, number of agglomerated particles and shear viscosity of the mixture were decreased in a similar manner, and the agglomerated number was well correlated by applied strain. On the other hand, in the agglomeration process of having reduced the shear rate applied, agglomerated number was increased after the increase in shear viscosity, when the mixture contained particles at a high volume fraction. Such a delay will be caused by the interaction between polymer entanglement structure and agglomerated particles. The internal structure of the mixture of particle and polymer was discussed in the consideration of frequency dependency of $\tan \delta$. When applying shear at shear rate more than the frequency where $\tan \delta$ showed the maximum, particle agglomerate was dispersed well, and the interaction between polymer and single particle mainly governs rheological behavior. In addition, if smaller shear rate was applied to the mixture after that, relaxation of entanglement structure will induce particle agglomeration.
\end{abstract}

Key Words: Polymer composite / Agglomeration / Entanglement structure / $\tan \delta$

\section{せん断流動下における溶融高分子中の微粒子凝集挙動}

\author{
菰田 悦之, 亀山 佳奈子, 長谷川 絵美, 鈴木 洋, 薄井 洋基
}

(原稿受理：2008 年 9 月 19 日)

\section{1. 緒言}

高分子材料と無機微粒子などのフィラーの混合物である ポリマーコンポジットは，その組み合わせによりさまざま な優れた機能性を示し, 用途に応じた素材が次々と世に送 り出されている。 また，フィラーをナノサイズ化したナノ コンポジットも近年注目されている. ${ }^{1}$ 一般にポリマーコンポ ジットでは, 高分子中の粒子含有量がその物理的強度に影 響を及ぼし ${ }^{2)}$, 粒子の分散状態を示すモルフォロジーが導電 性などの物性值と相関性があることが指摘されている.3. 製造 プロセスのみならず成型プロセスにおいては溶融状態にあ る高分子複合材料を取り扱うことになり, 溶融複合材料中 での微粒子分散挙動の理解や制御は製造プロセス設計にお いて非常に重要となる。本研究では, せん断作用が溶融高 分子中でのマイクロサイズ粒子の分散もしくは凝集挙動に 及ぼす影響について着目した。

これまでの分散状態評価手法としては, 光学顕微鏡や電 子顕微鏡による観察およびそれらの画像解析例は多く ${ }^{4)}$, 最

神戸大学大学院工学研究科応用化学専攻

T 657-8501 兵庫県神戸市灘区六甲台町 1-1

E-mail: komoda@kobe-u.ac.jp

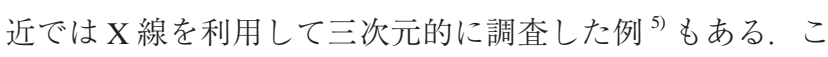
れら分散状態と物性との相関性についての研究例は多いが, 分散プロセスに着目した研究例は, フラクタル次元 ${ }^{6)}$ や粘弾 性特性 ${ }^{7}$ による解析例が幾つかあるが，あまり多くはない.

一方, 溶融状態にある微粒子高分子混合物のレオロジー 特性に関してはさまざまな研究が進められてきた. ${ }^{7-13)}$ 溶融高 分子中に微粒子が存在すると, 溶融高分子とは異なるレオ ロジー特性を示すはずであり, その特性変化が微粒子の分 散状態を反映すると考えられる。このようなアプローチは， フィラーの直接観察が困難なナノコンポジットでしばしば 用いられている手法である。例えば, Bar-Chaput と Carrot は, PEG中のカーボンフィラー凝集体サイズが貯蔵弾性率 の周波数依存性により相関できることを明らかにし7), 同様 の検討が他のグループによっても行われている. Warley らは高分子鎖が粒子表面に吸着されることで粘弾性 が発現し, 非定常せん断により応力が速やかに緩和するこ とを示した ${ }^{10,11)}$ また， Li と Salovey は PMMA 媒体中にPS 粒 子が分散した系でレオロジー特性を調べ，親媒体性粒子で は粘度が経時的に増加し，高い弾性率を示すことを明らか

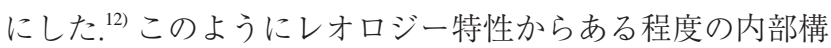
造は推定可能であるが, 間接的な測定方法であるので詳細 な微粒子分散状態の判断は難しい. 
また，高分子中における凝集体の破壊機構に関しては Feke らのグループを中心として広く研究が進められている. ${ }^{14-16)}$ 凝 集体破壊は主に剥離と開裂によって引き起こされ，ある值以 上のせん断応力で破壊が進むと報告している. ${ }^{14,15)}$ また, 非定 常せん断場であっても平均せん断速度により分散挙動を理解 できることが報告されており ${ }^{16)}$, せん断速度 · せん断応力と いった要素が粒子分散には大きく影響することがわかる。ま た, 粒子凝集に関しては, Vysotskii と Roldughin が低粘性液 体を分散媒としたサスペンジョン系とは異なりブラウン凝 集やせん断凝集ではその機構が説明できないとしており ${ }^{17)}$, Kozlov らが凝集体サイズの予測方法を提案している. ${ }^{18)}$

したがって，溶融高分子中の微粒子凝集体の流動場にお ける挙動を詳細に調査・予測するには, せん断速度が明確 なせん断流れ場において分散状態とレオロジー特性の経時 的変化の同時評価が必要である。そ己で, 我々は比較的低 温での温度差で溶融状態から固体に変化する高分子とシリ カ粒子の混合物を用い, コーンプレート型粘度計によって 溶融混合物に定せん断を印加し, 急冷固化することでさまざ まなせん断履歴を経た凝集状態を解析することができた ${ }^{19)}$ そ して, せん断印加時間が長く, 加えたせん断速度が大きい ほど分散が進むこと，せん断速度とせん断時間の積である ひずみに応じて微粒子が分散され，加えたせん断速度に応 じた凝集状態に収斂することを明らかにした。ささらに，分 散プロセスにおいて微粒子の分散と混合物粘度の低下は一 対一で進行するが, 再凝集プロセスにおいては粘度増加に おくれて微粒子が再凝集する傾向が見られた。

本稿では，この再凝集挙動に関して詳細な検討を行い， 動的粘弾性測定で得られる特性值との間に興味深い関係が 得られたので報告する.

\section{2. 実験}

\section{1 実験材料}

高分子としては, エチレンメチルメタアクリレート共重 合体 (EMMA)を用いた。 EMMAの物性值は, 重量平均分 子量 55000 , 融点 $67^{\circ} \mathrm{C}$, 密度 $891 \mathrm{~kg} / \mathrm{m}^{3}$, 体積膨張率 $5.8 \times$ $10^{-4} / \mathrm{K}\left(70{ }^{\circ} \mathrm{C}\right)$ である。 また, $120^{\circ} \mathrm{C}$ の溶融状態においてコー ンプレート型粘度計 (SR-5, Rheometric Scientific, コーン径

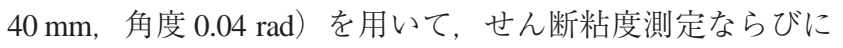
動的粘弾性測定を行った (Fig. 1).

せん断粘度はせん断速度の増加に対して緩やかに減少す るが, せん断速度 $0.1 ~ 10 \mathrm{~s}^{-1}$ で $180 \mathrm{~Pa} \cdot \mathrm{s}$ とほぼ一定であった

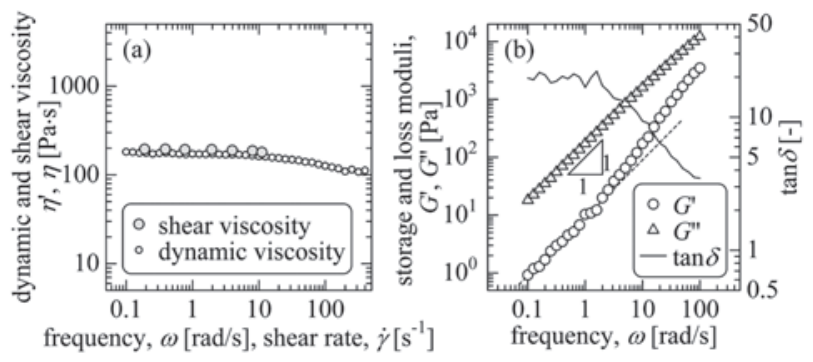

Fig. 1. Rheological characteristics of molten EMMA.
(Fig. 1(a)). 本研究で取り扱うせん断速度は $10 \mathrm{~s}^{-1}$ 以下であり, 溶融 EMMA は一定粘度を示す流体として取り扱えると考え た。また, せん断粘度のせん断速度依存性と動的粘度の周波 数依存性が良好な一致を示した。 したがって, Cox-Mertz 則 から, 動的粘弾性測定における周波数はせん断速度に対応す ると考えてよいことがわかった。 さらに，損失弾性率が周 波数に対してほぼ比例関係にあり, 周波数 $1 \mathrm{rad} / \mathrm{s}$ 以下では $\tan \delta$ が周波数に対して大きくは変化しないので溶融 EMMA は純粘性流体に近い挙動を示すことがわかった (Fig. 1(b)). 一方，それ以上の周波数では貯蔵弾性率の増加や $\tan \delta$ の減 少が見られ，周波数 $10 \mathrm{rad} / \mathrm{s}$ 以上で顕著であった。これらの 結果から, 比較的速い変形に対しては, 定常せん断場では 高分子鎖の絡み合い構造の一部が破壊されることで粘度は 低下し，周期せん断場ではその構造に起因した弾性が顕在 化したと考えた。

分散粒子としては単分散球形シリカ粒子 KE-P250（日本触 媒）を用いた。粒子径は $2.25 〜 2.75 \mu \mathrm{m}$, 比重は 2.0 である. シリカ粒子と EMMA ペレットをエタノールで懸濁し, 超音 波照射により分散および脱法する。その後, この混合物を 適宜混ぜながら $200{ }^{\circ} \mathrm{C}$ まて加熱すると, エタノールは除去 され，溶融 EMMA とシリカ粒子から成る混合物を得た。こ れらの加熱・混合プロセス前後で EMMAのレオロジー特性 の変化や気泡の発生はない. 本研究においては, 仕込み時 シリカ粒子の体積分率 $\phi$ を 0.10,0.15,0.25 として EMMA との 混合物を調製した。 EMMA は熱膨張するため溶融状態では シリカ粒子の体積分率は若干減少するが, 仕込み時の体積 分率は実験条件を表すパラメーターとして用いた。

\section{2 実験手順}

上記の操作によって調製した混合物中でシリカ粒子は見 かけ上均一に分散しているが，詳細に分散状態を調査すると 観察場所によるバラツキが非常に大きい。本研究では，予 備せん断により一定凝集状態を得た後, 所定のせん断履歴 を加え, 凝集状態の推移を調査した。前報では $\phi=0.15$ を対 象として予備せん断条件を, せん断速度 $0.1 \mathrm{~s}^{-1}$, せん断引加 時間 1000 秒と決定し, 凝集状態を一定化できることを報告 した ${ }^{19)}$ 今回, $\phi=0.10$ および 0.25 においても粒子体積分率に より異なるが同じせん断条件で一定の凝集状態が得られる ことがわかった。

コーンプレート型粘度計のコーンープレート間に溶融状 態にある EMMA・シリカ混合物を挿入し, ペルチェ式温度 コントローラーによりプレート部を $120{ }^{\circ} \mathrm{C} に$ 保持した。 そ して, コーンープレート間隔を所定の值に設定したあと, 試 料温度が定常になるまで暫く待って, 予備せん断を行った。 その後, 設定したせん断履歴に応じてせん断速度をステッ

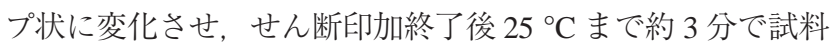
を冷却した。固化混合物中には，加えられたせん断履歴を 反映した粒子の凝集状態が保持されていると考えた。再凝 集挙動を調査する場合には, 予備せん断後, あるせん断速 度にて分散状態が安定するまでせん断を加えたあと，せん 断速度を再び低下させ，一定時間のせん断を加えた後，分 散操作と同様に混合物を冷却固化した。

分散および再凝集中に混合物粘度の経時変化も測定し, 所定のせん断履歴を経て冷却固化する前に動的粘弾性測 定を行った。動的粘弾性測定条件は，ひずみ $1 \%$, 周波数 
0.1 〜 $100 \mathrm{rad} / \mathrm{s}$ である.なお， せん断印加後にせん断を加え なかった場合, 少なくとも 1000 秒間には粒子の再凝集が認 められないことを確認している。 このため, せん断印加終 了から冷却開始までの時間のバラツキによる凝集状態の変 化は無視できると考えた。 また, 動的粘弾性測定における ひずみの大きさも，分散および再凝集プロセスにて加えら れたひずみに比べると十分に小さく, 動的粘弾性測定が微 粒子凝集状態に及ぼす影響は無視してよいと考えた。

コーンープレート間に挟まれた円形膜状の固化混合物をミ クロトームを用いて任意の円弧を切り取り, シリカ粒子が分 散した EMMA 薄膜を得た。この薄膜サンプル表面を電子顕 微鏡 (SEM)(JSM-5601, JEOL) により観察し (Fig. 2), シリカ粒 子の凝集状態を調査した。SEM写真中において，粒子同士 が重なり合っている状態にあれば凝集していると考え, 凝集 体約 200 個を対象として, それぞれの凝集体を構成する粒子 数を計測した．全シリカ粒子数に対する構成粒子数が $n$ 以下 の凝集体に含まれる粒子数の割合 $f_{\mathrm{n}}$, 平均構成粒子数 $n_{\mathrm{ave}}$ を 次式で定義し, 凝集状態を表現するパラメーターとした.

$$
\begin{aligned}
& f_{n}=\left\{\sum_{i=1}^{n}\left(i \cdot N_{C}(i)\right) / \sum_{i}\left(i \cdot N_{C}(i)\right)\right\} \times 100 \\
& n_{\mathrm{ave}}=\left\{\sum_{i}\left(i \cdot N_{C}(i)\right) / \sum_{i} N_{C}(i)\right\} \times 100
\end{aligned}
$$

ここで, $N_{\mathrm{C}}(i)$ は構成粒子数が $i$ 個の凝集体数である.

\section{3. 結 果}

\section{1 分散・凝集挙動に及ぼす粒子分率および せん断速度の影響}

各粒子体積分率 $\phi$ の混合物に対して, 予備せん断後にせ ん断速度をステップ状に上昇させ，平均構成粒子数の変化 を調査した，前報では $\phi=0.15$ の場合に，せん断速度とせん 断時間の積であるひずみと平均構成粒子数の間に良好な相 関性があり，十分なひずみが加えられるとせん断速度によっ て決まるある值に平均構成粒子数は漸近することを明らか にした。 また，也ん断速度が異なっても，平均構成粒子数 が定常に到達するまでには 1000 秒以上のせん断印加が必要 であることもわかった。

本研究では, 異なる粒子体積分率で同様の調査を行い, その結果を Fig. 3 にまとめた。 これより, せん断速度 $1 \mathrm{~s}^{-1}$ の時には，定常值までに要するせん断印加時間および，そ れまでの平均構成粒子数の推移に同様の傾向が認められた. したがって, 分散挙動に関しては粒子体積分率の影響は比 較的小さいと考えた

次に, せん断速度 $1 \mathrm{~s}^{-1}$ で 1000 秒間のせん断を加えて安定 な凝集状態に到達したあと，せん断速度を $0.1 \mathrm{~s}^{-1}$ までステッ プ状に低下させた時の再凝集挙動について調査した。各粒 子体積分率の混合物を用いたときの, 凝集体構成粒子数の 積算頻度分布を Fig. 4 にまとめた.

これより，粒子体積分率が高いほど積算分布の変化は小 さく，再凝集があまり進まないことがわかった。粒子体積

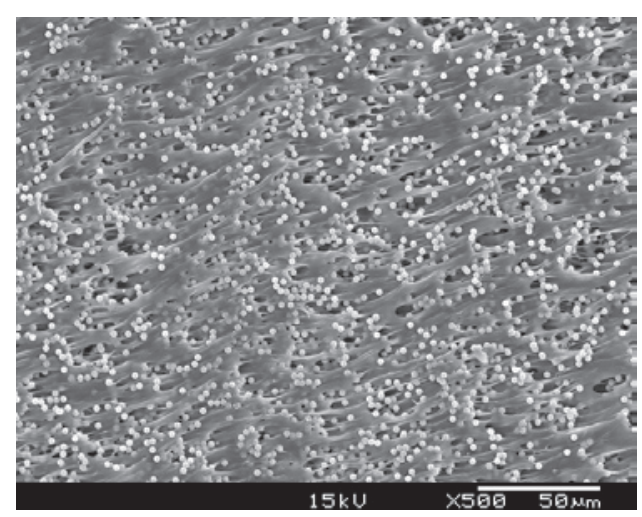

Fig. 2. SEM image of dispersed silica particles in EMMA matrix.

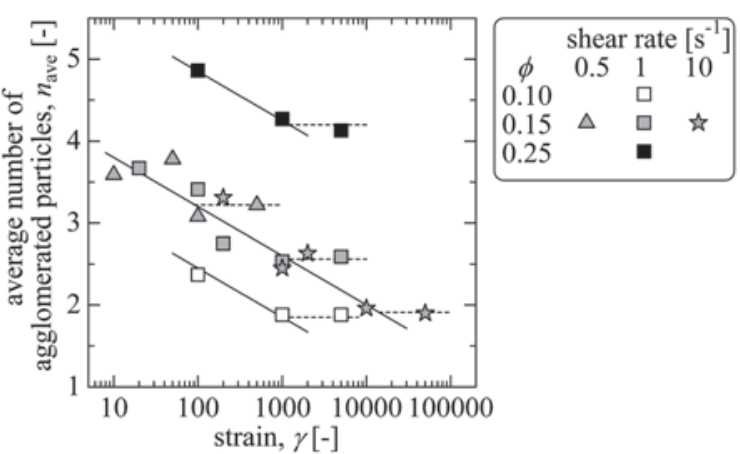

Fig. 3. Time variations of particle number in agglomerate in a dispersion process.
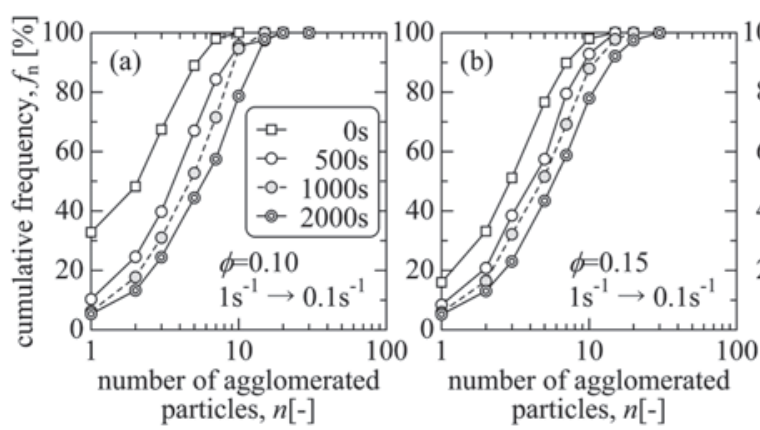

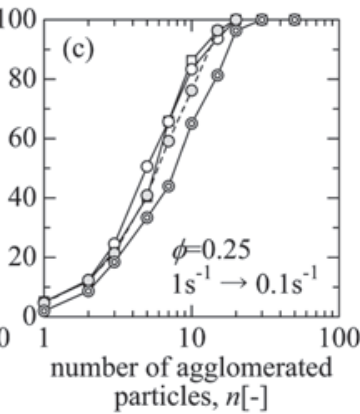

particles, $n[-]$

Fig. 4. Cumulative distributions of agglomerated number in an agglomeration process. 
分率が低い場合 $(\phi=0.10)$ には再凝集直前 (0s) には完全分散 粒子（構成粒子数 =1）の割合が $30 \%$ 程度と高いが, 粒子 濃度が高い $\phi=0.25$ では数％程度の粒子しか完全には分散 していなかった，粒子濃度が高くなると平均粒子間距離は 短くなるので完全分散粒子の割合が低下することは予想さ れるが, 再凝集過程において粒子間距離が長い低粒子濃度 の場合に顕著な凝集が認められた。これは, 粒子間距離だ けでは再凝集挙動が説明できないことを示している。

そこで, 粒子体積分率 $\phi=0.25$ の混合物を用いて, せん断 速度を $6 \mathrm{~s}^{-1}$ から 0.1 もしくは $1 \mathrm{~s}^{-1}$ に低下させ, 高分散状態か らの再凝集挙動を調査した (Fig. 5). まず, Fig. 5 と Fig. 4(a) の初期分散状態 (0s) を比較すると, いずれも完全分散粒子 が約 $30 \%$ で構成粒子数が 5 個以下の凝集体が約 $85 \%$ であ $\eta$, 再凝集前の初期条件は粒子体積分率 $\phi=0.10$, せん断速 度 $1 \mathrm{~s}^{-1}$ の定常分散状態と同等であることがわかる。 そして, Fig. 5(a) からせん断速度が $0.1 \mathrm{~s}^{-1}$ の時は, せん断速度の低下 直後に著しい再凝集が認められるものの, その後の凝集状 態はほとんど変化せず, Fig. 4(a) とは異なる再凝集挙動を示 した. また, このときに到達した定常分散状態では, 完全分 散粒子が $10 \%$ 程度とせん断速度 $1 \mathrm{~s}^{-1}$ からせん断速度を低下 させた場合 (Fig. 4(c)) の定常分散状態よりも高分散であった. これに対して, せん断速度を $6 \mathrm{~s}^{-1}$ から $1 \mathrm{~s}^{-1}$ に低下させた場 合 (Fig. 5(b)), 全体的に構成粒子数は減少するが, 顕著な再 凝集挙動は見られなかった。

以上の結果より, せん断流れによって比較的短い時間ス ケールで再凝集は進むが, 加えられているせん断速度だけ ではその挙動が説明できず, 初期分散状態の影響も極めて 大きいことが明らかになった。したがって, 再凝集挙動を 理解するためには, 分散プロセスのせん断速度を一定にし ての議論が必要である。

\section{2 分散および再凝集時における構成粒子数と粘度の関係}

EMMAの分子量は比較的低いことから混合物のせん断粘 度は粒子濃度により大きく影響され ${ }^{13)}$, それに加えて, 粒 子凝集による粘度増加 ${ }^{12)}$ も無視できないと考えられる。し たがって, このせん断粘度の変化は粒子分散状態を理解す る上で有用な情報と考えられる。 そこで, 予備せん断後（也 ん断速度 $0.1 \mathrm{~s}^{-1}$ での定常状態）からせん断速度を $1 \mathrm{~s}^{-1}$ そし て $0.1 \mathrm{~s}^{-1}$ に変化させ, それぞれのせん断速度で 1000, 5000（も しくは 10000）秒間保持したときの平均構成粒子数と混合物
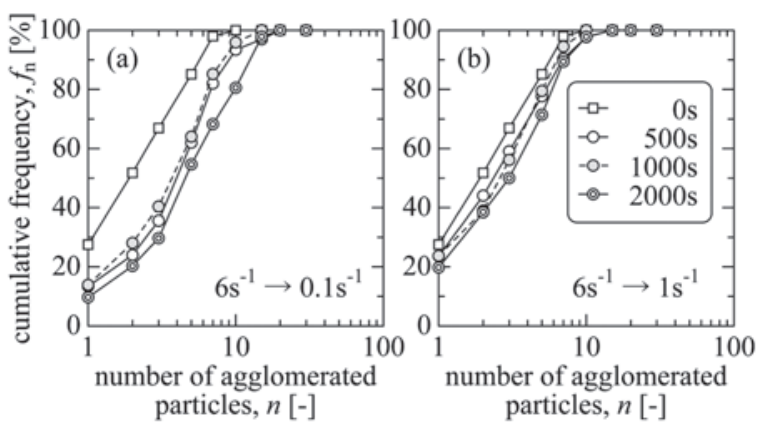

Fig.5. Agglomeration processes from the dispersion process at shear rate of $6 \mathrm{~s}^{-1}$ for the mixture of $\phi=0.25$.
粘度の経時変化を, Fig. 6 にまとめた

この実験において加えたせん断履歴は，予備せん断・分散・ 再凝集と連続的なプロセスを想定しているが，本実験で採 用した解析手法では凝集状態の推移を連続的に調査するこ とはできない.したがって, Fig. 6における平均構成粒子数は, ある時点までの履歴に対応するせん断を加えたあとに急冷 固化し, 凝集状態を調査する操作を繰り返して得た。 また, 粘度は急冷固化直前の測定值を用い, 凝集状態がひずみの 対数に対して直線的に変化することから, 時間軸は部分的 に対数表記とした。

まず，分散プロセスに着目する。いずれの粒子体積分率 においても対数時間軸に対して構成粒子数はほぼ直線的に 変化した. 分散プロセスのせん断速度が $1 \mathrm{~s}^{-1}$ であることから, 横軸は加えたひずみと等価であり，この結果は Fig. 3 の結果 と良好に一致している。また，混合物粘度も概ね同様の傾 向を示したが, $\phi=0.10$ および 0.25 ではせん断印加初期に大 幅な粘度低下が見られた。これは, せん断速度変更直後に

(a) $\phi=0.10$

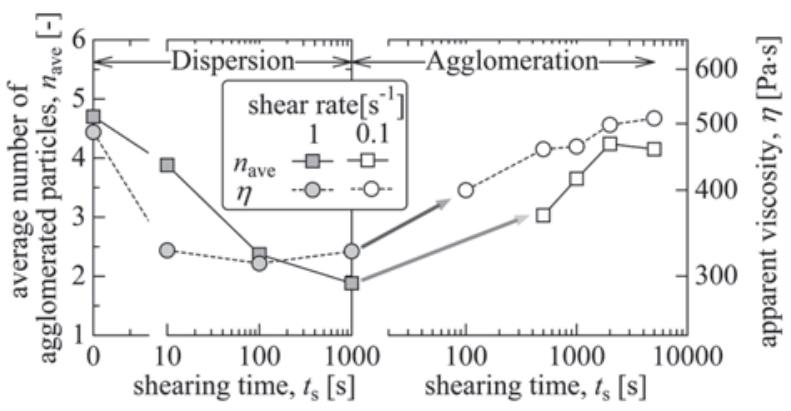

(b) $\phi=0.15$

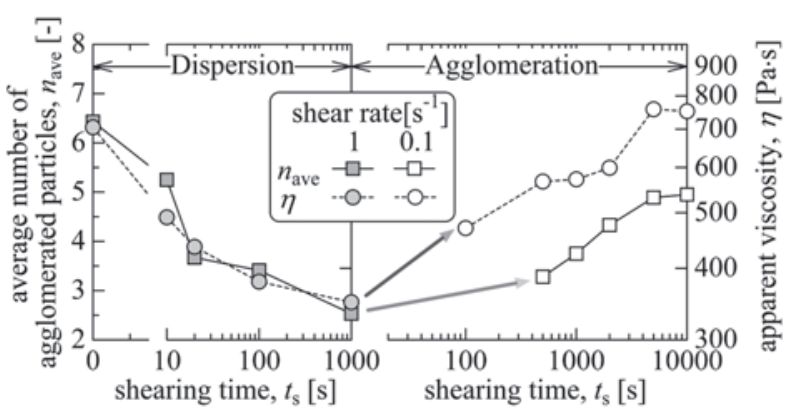

(c) $\phi=0.25$

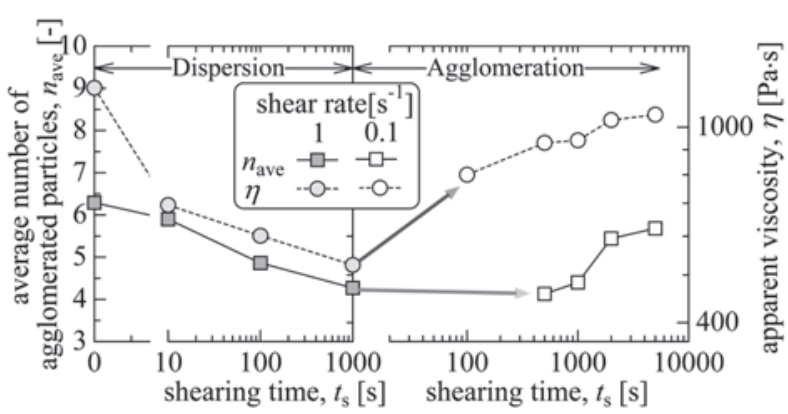

Fig. 6. Time variations of agglomerated number and apparent viscosity in dispersion and agglomeration processes. 
はせん断速度が安定するまで暫く時間を要するため, 適切 なせん断速度でせん断が加えられていなかった可能性が考 えられる。これらの結果から, 分散プロセスにおいては微 粒子分散状態と混合物粘度が概ね良好な対応関係を保持し ながら推移することがわかった。

次に, 再凝集プロセスに着目すると, 粒子体積分率によっ て平均構成粒子数と混合物粘度の挙動が著しく異なる傾向 が見られた。すなわち，粒子体積分率 $\phi=0.10$ の場合には， 粘度. 平均構成粒子数のいずれもせん断速度を低下させた あと速やかに増加し, 分散プロセスと同様に良好な対応関 係がある。しかしながら， $\phi=0.15$ では，粘度は $\phi=0.10$ の ときと同様に速やかに上昇したが, 平均構成粒子数は再凝 集初期においてあまり増加しなかった。また，粘度はせん 断速度が等しい予備せん断後と同等の值にまで回復したが, 構成粒子数は粘度増加に遅れて増加し, 分散初期の值にまで

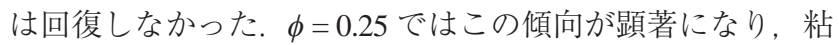
度が分散プロセス開始前と同等の值にまで回復してから構 成粒子数が徐々に増加し, 予備せん断後の值にまで回復し なかった。 このように, 再凝集プロセスにおいては, 粒子 体積分率が高い場合には, 混合物粘度はせん断速度の減少 に応じて増加するが, 再凝集はせん断速度の変化に対して 遅れて進むことから, 粘度と凝集状態の間には対応関係が 見られないことがわかった。

次に, 粘度に対する再凝集挙動の遅れが顕著であった $\phi=0.25$ の混合物を用い, 分散プロセスのせん断速度を $6 \mathrm{~s}^{-1}$, 再凝集プロセスのせん断速度を $0.1 も し く は ~ 1 \mathrm{~s}^{-1}$ とした場合 について粘度と構成粒子数の推移を調査した (Fig. 7). なお, 予備せん断のせん断速度は, 再凝集プロセスのせん断速度 と同じとした。

(a) $0.1 \mathrm{~s}^{-1} \rightarrow 6 \mathrm{~s}^{-1} \rightarrow 0.1 \mathrm{~s}^{-1}$

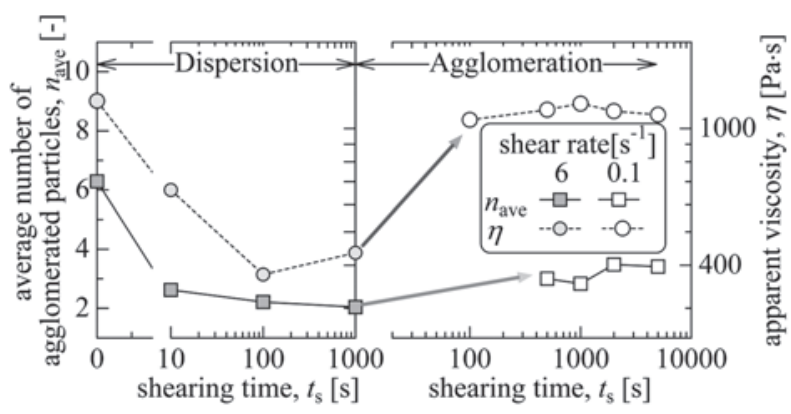

(b) $1 \mathrm{~s}^{-1} \rightarrow 6 \mathrm{~s}^{-1} \rightarrow 1 \mathrm{~s}^{-1}$

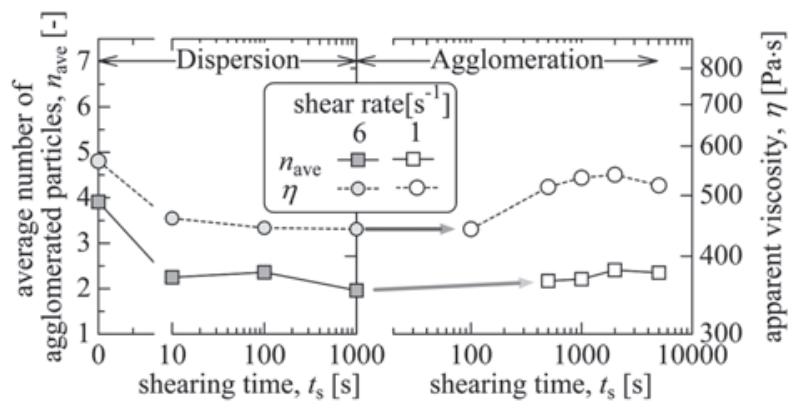

Fig. 7. Behaviors of agglomerated number and viscosity containing the dispersion process at high shear rate.
まず分散プロセスに着目すると，せん断速度が $6 \mathrm{~s}^{-1}$ と大 きいために構成粒子数が著しく低下し，それに応じて混合 物粘度も減少した。粒子体積分率 $\phi=0.10$ でせん断速度が $1 \mathrm{~s}^{-1}$ の場合と $\phi=0.25$ で $6 \mathrm{~s}^{-1}$ の場合の定常分散状態は同等で ある (Fig. 4(a), Fig. 5(a)) ので，せん断速度が $6 \mathrm{~s}^{-1}$ であれば凝 集体は良好に分散される，構成粒子数と粘度との減少傾向 は良好に一致し, 到達した粘度や構成粒子数は, 予備せん 断におけるせん断速度によらずほぼ一致した。次に, 再凝 集プロセスに着目すると，せん断速度 $0.1 \mathrm{~s}^{-1}$ で再凝集させた 場合, 混合物粘度は 100 秒以内に予備せん断後と同等の值に まで回復した。構成粒子数の増加は見られたが, 分散プロ セスのせん断速度が $1 \mathrm{~s}^{-1}$ の場合 (Fig. 6(c)) に比べて，その変 化は小さかった。ささらに，再凝集プロセスのせん断速度が $1 \mathrm{~s}^{-1}$ の場合には, 粘度はやや遅れて増加し, 構成粒子数はほ とんど変化しなかった。

以上のことから, 予備せん断および分散プロセスでのせ ん断履歴にかかわらず, せん断速度を低下させると混合物 粘度は増加し, そのときのせん断速度に応じた值にまで回 復する。 これに対して, 構成粒子数は加えられているせん 断速度によって決まる值に収束するわけではなく, 再凝集 前の分散状態の影響も受けることがわかった。 したがって, 分散プロセスにおいて混合物粘度は凝集状態を表す指標と 考えられたが, 再凝集プロセスにおいては混合物粘度だけ からは凝集構造を推定できないことがわかった。

\section{4. 考察}

\section{1 動的粘弾性測定による微粒子分散・凝集機構の推定}

再凝集挙動を詳細に理解するためには，せん断粘度だけで はなく, 高分子マトリックスと分散粒子との相互作用を考慮 した考察が不可欠である。高分子鎖の粒子表面への吸着 ${ }^{10)}$ やナノサイズフィラーのネットワーク構造形成 ${ }^{1)} に よ り$ 混合 物は粘弾性を発現し, 逆に, 貯蔵弾性率や $\tan \delta$ の周波数依 存性から高分子と粒子の相互作用を推測する方法が提案さ れている.,7-9) 本実験系では，粒子が大きいためにネットワー ク構造を形成することはないと考えられるが, 動的粘弾性 測定結果は粒子と高分子によって形成される内部構造を反 映することが予測される.

そこで, 溶融 $\operatorname{EMMA}(\phi=0)$ と溶融混合物 $(\phi=0.10,0.15,0.25)$ を対象とし, 予備せん断（也ん断速度 $0.1 \mathrm{~s}^{-1}$ ) 後の試料を用 いて, 貯蔵弾性率と $\tan \delta$ の周波数依存性を調べた (Fig. 8). 分散粒子がネットワークを形成すると低周波数域で眝蔵弾 性率の平坦部が見られるが, 本実験系ではそのような傾向 は見られず粒子が内部構造を形成しているとは考えられな い。ただ, 粒子添加により貯蔵弾性率は増加し, ある周 波数以上で依存性（=傾き）が変化することから, 高分子の 絡み合い構造の変化が粒子の存在によって影響を受けてい

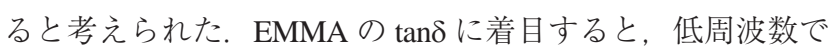
大きく変化しないが, 周波数の増加に伴って減少する。 こ れはすでに述べたように，緩やかな変形に対して絡み合い 構造の影響は小さく, 速い変形に対してはその影響が顕著 になることを示している。一方, 溶融混合物の $\tan \delta$ は, 粒 子濃度によらず周波数が 1 から $10 \mathrm{rad} / \mathrm{s}$ の間で極大值を示し た. Warelyらによると粒子表面と高分子の絡み合い構造が 付着して粘弾性を発現するとされており ${ }^{10)}$, 低周波数域で 
の $\tan \delta$ の増加は EMMA がシリカ粒子に付着して形成される 構造に, 高周波数域での $\tan \delta$ の減少は EMMA の絡み合い構 造に起因すると考えた。すなわち, 遅い変形の場合は粒子 表面へ EMMA が付着することで絡み合い構造の変形が抑制 されるが, 変形が速くなるにつれて粒子との付着効果が弱 くなるために絡み合い構造が変形しやすくなり, さらに速 い変形では絡み合い構造の崩壊が現象を支配する。そ己で,

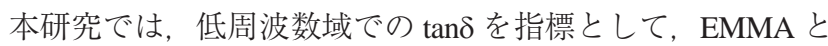
シリカ粒子との相互作用について考察した.

粒子体積分率 $\phi=0.25$ の混合物を用いて，せん断速度 0.1,1 および $6 \mathrm{~s}^{-1}$ で凝集状態および粘度が定常に到達した後に $\tan \delta$ の周波数依存性を調査した (Fig. 9). 加えたせん断速度 が大きくなるほど低周波数域において $\tan \delta$ が増大し，また， 構成粒子数は減少したことから，粒子が良好に分散される と絡み合い構造の変形の抑制効果が小さくなると考えられ る.さらに注目すべき点として, 低せん断速度で分散した 混合物では周波数が大きくなるにつれて $\tan \delta$ は増加したが, せん断速度 $6 \mathrm{~s}^{-1}$ で分散した場合には $\tan \delta$ はほぼ一定であっ た. $\tan \delta に$ 極大值が見られないことは，変形速度に関係なく 絡み合い構造の変形に対する凝集体の影響が極めて小さい ことを示唆している。すなわち, せん断速度が $6 \mathrm{~s}^{-1}$ 以上で あれば粒子は十分に分散され，単一粒子と高分子鎖で形成 する内部構造がその時のレオロジー特性を支配していると 推定した。

次に, Fig. 4(c), Fig. 5(a)(b) に対応するせん断速度にて予 備せん断, 分散, 再凝集をそれぞれ 1000 秒間行った混合物 について, $\tan \delta$ の周波数依存性を調べ, Fig. 10 にまとめた. せん断速度 $1 \mathrm{~s}^{-1}$ もしく $6 \mathrm{~s}^{-1}$ で分散後, せん断速度を $0.1 \mathrm{~s}^{-1}$ に下げた場合 (Fig. 10(a),(b)), せん断速度により tan $\delta$ は異な
るものの，せん断速度を下げて十分に時間が経過すれば分散 前の $\tan \delta$ へ回復した。 これに対して，せん断速度を $6 \mathrm{~s}^{-1}$ から $1 \mathrm{~s}^{-1}$ に低下させた場合 (Fig. 10(c)), $\tan \delta$ は分散前の状態 にまで完全には回復しなかった。いずれの条件でもせん断 時間は一定であるので，再凝集プロセスにおける混合物の 変形量はせん断速度に比例する。したがって，せん断速度 $1 \mathrm{~s}^{-1}$ で再凝集させた場合には，混合物に対して大きな変形を 与えているにもかかわらず，再凝集が進み難かったことを 示している.

これらの結果から，凝集体構成粒子数および混合物粘度 の変化のメカニズムを以下のように推測した，構成粒子数の 変化は混合物に加えられた変形量だけでは説明できず，せん 断破壊やせん断凝集が支配的ではないことを示唆している. EMMA の鎖長（約 $0.3 \mu \mathrm{m} ）$ は分散粒子の大きさ（約 $2.5 \mu \mathrm{m}$ ) に比べて小さいが，高分子鎖の絡み合い構造は分散粒子よ りも大きいと推定できる。したがって, 粒子は絡み合い構 造に拘束されていると考えると, 絡み合い構造の変形によっ て粒子は分散もしくは凝集する。すなわち, 高いせん断速度 では, 絡み合い構造は引き伸ばされて凝集体は壊れる。逆に, 低いせん断速度では，絡み合い構造がまず収縮した構造へ 緩和し，拘束された粒子はそれに遅れて引き寄せられ凝集 する，ただし，粒子が十分に分散されると（例えば，せん 断速度 $6 \mathrm{~s}^{-1}$ での定常分散状態)，絡み合い構造が単一粒子を 含んだ状態で安定になり，さらに，せん断速度の低下が小 さいと，絡み合い構造の緩和が起こり難く，粒子もほとん ど凝集しないことになる。また，絡み合い構造の変形も粒 子によって抑制されるので，混合物は EMMA に比べて高い 応力すなわち高い粘度を示し，高分子鎖と粒子との相互作 用により粘度は変化する。ただし，絡み合い構造自体も変
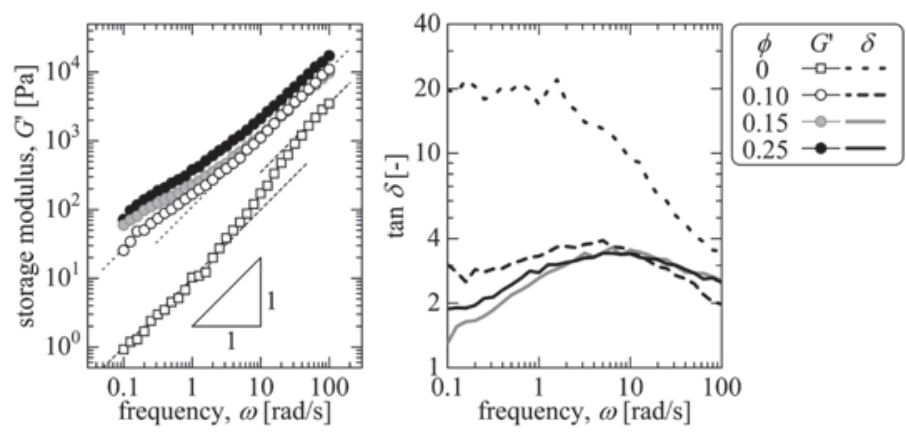

Fig. 8. Dynamic rheological properties of polymer and mixture melt after preshearing process.

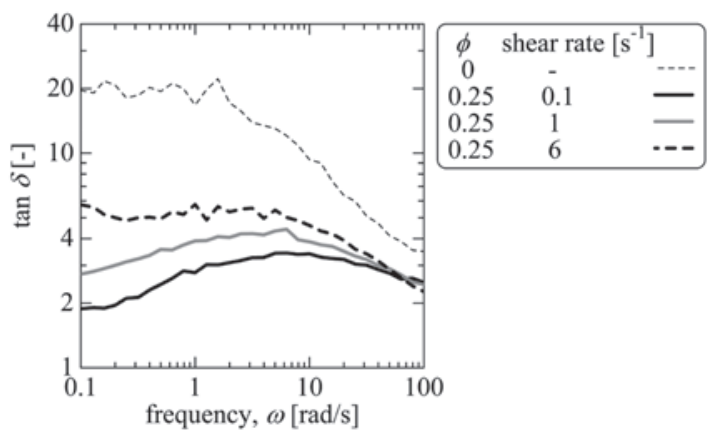

Fig. 9. Frequency dependence of $\tan \delta$ for applied shear rates.
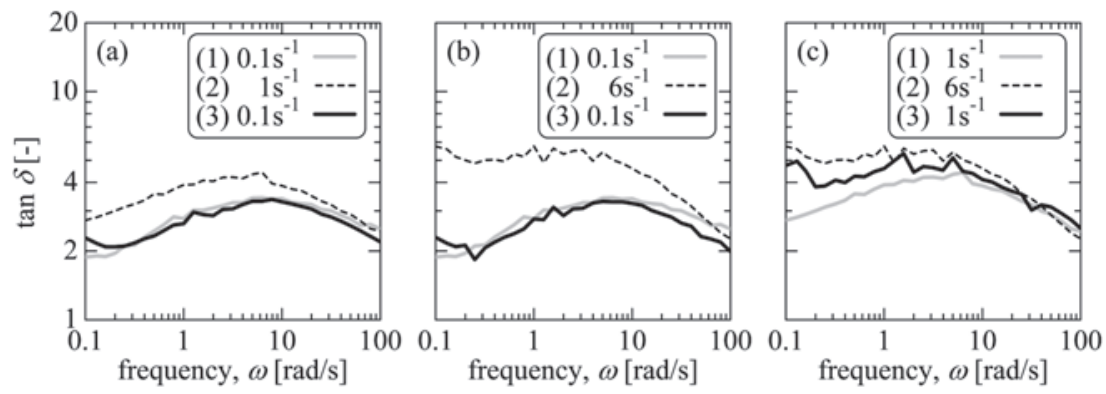

Fig. 10. Frequency dependence on tan $\delta$ corresponding to applied shear history. 
形に伴って応力を生ずるが, 本実験条件では粒子数が少な いので絡み合い構造自体が応力に及ぼす影響は小さくない. 高せん断場では, 粒子凝集体が分散され, 絡み合い構造の変 形があまり抑制されないので応力は低下する。一方, 低せ ん断場では, 絡み合い構造自体の緩和が支配的になり, 粒 子凝集の前に粘度が増加する。ただし, 良分散状態では絡 み合い構造に対する粒子の影響が大きいので, 絡み合い構 造自体の緩和が抑制され，せん断速度の低下から暫く後に 粘度は増加したと考えた。

\section{5. 結言}

溶融高分子とミクロンオーダーの微粒子混合物に定常せん 断を加え, 微粒子凝集体の分散㧍よび再凝集挙動について 調査した。分散プロセスでは, せん断印加時間に応じて粘 度と凝集体構成粒子数が同時に減少し, 粘度が凝集状態を 推測するパラメーターに成り得ることがわかった。 これに 対して, 再凝集プロセスでは, 粘度と構成粒子数の推移は 粒子含有量や再凝集直前の凝集状態によって大きく異なり, 粘度だけは速やかに回復するが, 特に粒子濃度が高い場合 に再凝集は粘度変化に遅れて始まることがわかった。

$\tan \delta$ を指標として高分子鎖と粒子の相互作用を考慮し, 再 凝集プロセスについて考察した. $\tan \delta$ が極大となるせん断速 度以上で分散すると, 粒子は良好に分散されて, 単一粒子 を含む絡み合い構造が挙動を支配すると考えられた。この 構造を保持できる高いせん断速度を加え続ければ粒子は再 凝集しないが, 逆に, せん断速度が低い場合や凝集構造が 残存している場合には絡み合い構造の緩和により凝集が進 むことがわかった，ただし，絡み合い構造が粒子の凝集を 引き起こす点については, 粒子と高分子の大きさを種々変 化させた場合についても検証を行った上で, 再度考察する 必要があると考えられる。

本研究から得られた知見から, 微粒子を適度に均一分散 した混合物の動的粘弾性測定を行えば，再凝集を抑制でき るせん断速度を推定できると考えられる。 また, 高せん断 を加えて微粒子を十分に分散できても, 低せん断流動場で 長時間保持すると微粒子の再凝集が促進されるとも言える.

\section{REFERENCES}

1) Jordan J, Jacob KI, Tannenbaum R, Sharaf MA, Jasiuk I, Mater Sci Eng A, 393, 1 (2005).

2) Selvina TP, Kuruvillab J, Sabua T, Mater Letters, 58, 281 (2004).

3) Wu G, Lin J, Zheng Q, Zhang M, Polymer, 47, 2442 (2006).

4) Karasek L, Sumita M, J Mater Sci, 31, 281 (1996).

5) Wu D, Gao D, Mayo SC, Gotama J, Way C, Compos Sci Technol, 68, (2008).

6) Mizuno Y, Shimizu T, Terashita K, Miyanami K, J Soc Mat Sci, Japan, 42, 836 (1993).

7) Bar-Chaput S, Carrot C, Rheol Acta, 46, 339 (2006).

8) Raghavan SR, Riley MW, Fedkiw PS, Khan SA, Chem Mater, 10, 244 (1998).

9) Wu G, Asai S, Sumita M, Hattori T, Higuchi R, Washiyama J, Colloid Polym Sci, 278, 220 (2000).

10) Warley RL, Feke DL, Manas-Zloczower I, J Appl Polym Sci, 98, 1001 (2005).

11) Warley RL, Feke DL, Manas-Zloczower I, J Appl Polym Sci, 104, 2197 (2007).

12) Li JQ, Salovey R, Polym Eng Sci, 44, 452 (2004).

13) Park M, Salovey R, Polym Compos, 20, 534 (1999).

14) Rwei SP, Manas-Zloczower I, Feke DL, Polym Eng Sci, 30, 701 (1990).

15) Lee YJ, Manas-Zloczower I, Feke DL, Polym Eng Sci, 35, 1037 (1995).

16) Boyle J, Manas-Zlczower I, Feke DL, Part Part Syst Charact, 21, 205 (2004).

17) Vysotskii VV, Roldughin VI, Colloid Journal, 62, 685 (2000).

18) Kozlov GV, Mirzoev RS, Lipatov YS, Mech Compos Mater, 38, 169 (2002).

19) Komoda Y, Kameyama K, Hasegawa E, Suzuki H, Usui H, Endo Y, Syudo A, Advanced Powder Technol, 19, 507 (2008) 